\title{
Together toward Christ: Comparing Orthodox and Wesleyan Positions on Evangelism
}

\author{
Kristina Whiteman ${ }^{1,2}$ (D) \\ 1 Asbury Theological Seminary, Orthodox Christian Mission Center, Wilmore, KY 40390, USA; \\ k.whiteman@ocmc.org \\ 2 Mission Specialist in Care and Training States, St. Augustine, FL 32086, USA
}

Citation: Whiteman, Kristina. 2021. Together toward Christ: Comparing Orthodox and Wesleyan Positions on Evangelism. Religions 12: 495. https://doi.org/10.3390/rel12070495

Academic Editors: Bradley Nassif and Tim Grass

Received: 28 May 2021

Accepted: 29 June 2021

Published: 2 July 2021

Publisher's Note: MDPI stays neutra with regard to jurisdictional claims in published maps and institutional affiliations.

Copyright: (C) 2021 by the author. Licensee MDPI, Basel, Switzerland. This article is an open access article distributed under the terms and conditions of the Creative Commons Attribution (CC BY) license (https:/ / creativecommons.org/licenses/by/ $4.0 /)$.

\begin{abstract}
Inspired by the events of the 2018 consultation of the Lausanne-Orthodox Initiative, this brief article seeks to pare down the broader question of "greater Christian unity" within the North American sphere to a more digestible, specific, practical question: How do Wesleyan and Orthodox positions on evangelism compare? This question is examined by describing the Wesleyan and Orthodox views of evangelism, delineating some key similarities and differences, and proposing a way forward for Wesleyans and Orthodox, together toward Christ.
\end{abstract}

Keywords: ecumenism; Wesleyan; Orthodox; evangelism; John Wesley; Lausanne-Orthodox Initiative

\section{Introduction}

In the summer of 2018, approximately sixty Eastern and Oriental Orthodox and Evangelical protestants gathered at Holy Cross Greek Orthodox School of Theology for a consultation of the Lausanne-Orthodox Initiative. ${ }^{1}$ As a convert with both deep gratitude for my Wesleyan Free Methodist upbringing and devotion to the spiritual home I have found in Eastern Orthodoxy, I was deeply blessed by the opportunity to participate with these men and women, clergy and laity, from around the world. The days were filled with fellowship, with good discussions, and with some honest talk about what makes us the same and what makes us distinct. I walked away feeling hopeful-connected to others who feel as I do that this type of ecumenism, which seeks to love the Christian Other in order to better love the world, is pleasing to God. Yet, I also walked away feeling uncertain-concerned that the very real differences between us are enough to keep us constantly apart in any but the most superficial ways. Most importantly, I walked away feeling more strongly affirmed in the importance of relationships and the desire to see these two Christian Traditions work together for the sake of the world.

It is necessary to pare down the extremely broad "search for Christian unity" to a more digestible, more specific, more practical issue. As an Eastern Orthodox Christian, my own Tradition is a natural home-base for discussion. Due to the wide variety of theology and praxis within Protestantism, it is impossible to compare this group of groups with Orthodoxy: Wesleyan Christians make up a large group at the center of Protestantism, which, along with their clear united historical antecedents, makes them a manageable comparison group. Brought by missionaries to the North American context quite close to each other in time, each tied to a historic tradition but also creating something new, Wesleyan Christianity and Orthodox Christianity ${ }^{2}$ have been passed on and practiced in a unique way within this context.

At the heart of Christianity is witness; evangelism, then, is a proper place to begin efforts at greater unity through dialogue. This paper will examine the possibility of Wesleyan-Orthodox cooperation in the area of evangelism by: describing the Wesleyan and Orthodox views of evangelism, delineating some key similarities and differences, and proposing a way forward for Wesleyans and Orthodox. 


\section{Introductory Definitions}

By way of preamble, some definitions are in order. First of all, "Wesleyan" may be defined as the Christian Tradition which hews closely to the teachings and example of John Wesley, the founder of Methodism who is also the basis for many other Protestant denominations' theology and praxis. This paper will focus on the theology of evangelism specifically espoused by John Wesley himself.

Secondly, for the purposes of this paper, "evangelism" will be defined as the proclamation of the gospel of Jesus Christ (see, for example: Jackson 2012, pp. 46, 52, 57; Hynson 1982, p. 27; Ware and Neff 2011, p. 41; Nissiotis 1975, p. 86; Tosi 2014, p. 10; Rommen 2017, p. 187; Wesley 1738; Wesley 1785c). As will be seen in the further discussion, this proclamation may take varied forms, and it may be characterized as "witness," as "sharing God's good news," as "communicating the gospel,", etc. Ultimately, whatever words are used to describe it, all evangelism is an effort to tell the one story of the salvific Incarnation, death, and Resurrection of Jesus Christ.

\section{John Wesley and Evangelism}

Although John Wesley himself did not use the word "evangelism" (Jackson 2012, p. 50), certainly sharing the gospel message was a central theme of both his writing and his personal ministry. Wesley understood evangelism as a process: first of all, those who have received the gospel message share that message, either with those who have never heard or with those who call themselves Christians but lack the true "religion of love" (Wesley 1796, p. 21; see also Outler 1971, p. 23; Wesley 1796; Wesley 1786). Over time, those who hear are first "awakened" to their life of sin and need for God (Jackson 2012, p. 51; Wesley 1760, 1765; Wesley 1738). This awakening leads to repentance, repentance leads to faith (Hynson 1982, p. 30; Jackson 2012, pp. 52-53; Wesley 1760, 1765), and faith leads to justification, or conversion.

The fruits of evangelism do not stop with personal conversion, however: faith grows with a commitment to Christ and leads to love (Hynson 1982, p. 34; Wainwright 2002; Wesley 1765, 1789; Knight and Powe 2006; Wesley 1760). This love, first of God but also of others (Hynson 1982, p. 32; Jackson 2012, pp. 53-54; Wesley 1765, 1789; Wainwright 2002; Wesley $1733,1782,1786,1796)$, is not a mere emotion-it is more than an internal feeling. It is "faith active in love" (Hynson 1982, p. 31) through holy living, service to others, and verbal proclamation which is a confirmation of the gospel which has been received (Hynson 1982, p. 27; Jackson 2012, p. 51; Wesley 1760, 1765, 1785a, 1786). This becomes a self-perpetuating cycle, as those who take hold of the gospel cannot help but pass it on to others (Wesley 1733).

\section{Orthodoxy and Evangelism}

The words "evangelism," "mission," "witness," and "preach the gospel" are frequently used interchangeably by Eastern Orthodox Christians; in the American Orthodox Church ${ }^{3}$ in particular, evangelism is frequently tied to the Great Commission (See, for example, Schmemann 1959; additionally, each of the three largest American Orthodox jurisdictions (Antiochian Orthodox Christian Archdiocese of North America, The Orthodox Church in America, and the Greek Orthodox Archdiocese of America) mention the Great Commission in their material on Outreach/Evangelism/Mission). An Orthodox understanding of evangelism would include preaching Christ to those who are nominally or culturally Christian, in addition to those who are completely outside the Faith (Nissiotis 1975, pp. 86, 90; Stamoolis 1986, pp. 56, 98; Yannoulatos 2010, p. 19).

For Orthodox, evangelism includes holiness of life and an authentic personal witness of empathetic, vulnerable love (Hierarchs of the Standing Conference of the Canonical Orthodox Bishops in the Americas 2000, pp. 58, 64, 70; Nissiotis 1975, pp. 80, 91; Lemopoulos 1998, p. 324; Tosi 2014, p. 21; Bria 1996, p. 48; Whiteman 2019). Worship is an integral part of evangelism (Lemopoulos 1998, p. 324; Bria 1975, p. 248; Tosi 2014, p. 4; Whiteman 2019; Stamoolis 1986, p. 10, 86-94), but spreading the good news is also often 
seen as involving more than verbal proclamation. Because evangelism is primarily "letting our light shine," it can include activities such as care for the poor (Nissiotis 1975, pp. 79, 88; Hierarchs of the Standing Conference of the Canonical Orthodox Bishops in the Americas 2000, p. 64; Bria 1984, p. 67; Whiteman 2019; Yannoulatos 2010, p. 96).

The goal of evangelism is conversion to relationship with the Trinity through Christ (Nissiotis 1975, p. 87; Nassif 2004, p. 67; Lemopoulos 1998, p. 324; Tosi 2014, p. 4; Damick 2013, p. 16; Yannoulatos 2010, p. 148; Stamoolis 1986, p. 101); the "transmission of the life of communion which exists in God" (Nissiotis 1975, p. 78). Repentance, faith, and baptism go together (Nassif 2004, p. 79); it is in the Eastern Orthodox Church, which is itself the Eucharistic Community, that those who have been evangelized find this union with the Trinity in theosis and thus enter into the "'recapitulation of all things' (Eph 1: 1) in Christ and our participation in the divine glory, the eternal, final glory of God" (Yannoulatos 2010, p. 46).

\section{Key Similarities}

Wesleyan and Orthodox understandings of evangelism are certainly not identical, but they do have key similarities. For example, both Wesleyans and Orthodox Christians see evangelism as absolutely necessary rather than optional (Jackson 2012, p. 51; Hynson 1982, p. 40; Nissiotis 1975, p. 87; Hierarchs of the Standing Conference of the Canonical Orthodox Bishops in the Americas 2000, p. 57; Nassif 2004, p. 83; Rommen 2017, p. 177; Chrysostom 1997; Abraham 1989, p. 165). It is the task of the whole community of God to tell others about what God has done in the world in Jesus Christ (Nissiotis 1975, p. 90; Bria 1984, p. 67; Bria 1975, p. 245; Schmemann 1959; Halvorsen 2007, p. 280). Additional agreements can be found in three major areas: the role of the Trinitarian God, the role of human beings, and process-oriented transformation.

\section{Evangelism: The Trinitarian God at Work}

The Trinitarian God is always the primary actor in both perspectives on evangelism (Lemopoulos 1998, p. 322; Wesley 1775, 1780; Wainwright 2002; Wesley 1796, p. 6; Vassiliadis 2002, p. 105; Wesley 1790, 1785c; Yannoulatos 2010, p. 7). God the Father, through the Incarnation of the Son, in the Holy Spirit, is active at every step. An immanent God reaches out to human beings with salvation which is a free gift, open to all people (Tyson 2000, pp. 60, 61; Hierarchs of the Standing Conference of the Canonical Orthodox Bishops in the Americas 2000, pp. 61, 95; Rommen 2017, p. 194; Wesley 1736, 1738, 1750, 1782, 1790, 1796; Nassif 2004, p. 47; Hynson 1982, p. 28; Lemopoulos 1998, p. 324).

Both traditions believe that God has been at work in advance of evangelism, preparing the way in the midst of cultural and personal contexts (Tyson 2000, p. 67; Hierarchs of the Standing Conference of the Canonical Orthodox Bishops in the Americas 2000, p. 95; Nissiotis 1975, p. 77; Wesley 1765, 1780, 1788, 1796; Outler 1971, pp. 44-45). What Wesleyans would refer to as "prevenient grace" (Whiteman and Anderson 2009), Orthodox Christians might refer to as "spermatic Logos" (Hierarchs of the Standing Conference of the Canonical Orthodox Bishops in the Americas 2000, p. 96; Justin and Falls 1965). Both convey the idea that God has provided for all people a path toward the path of salvation, even long before human beings hear the name of Christ. In fact, the ability to respond to evangelism-faith itself-is a divine gift given by God through the Holy Spirit (Nassif 2004, p. 74; Hynson 1982, p. 29; Wesley 1760, 1790, 1796; Tyson 2000, p. 52; Jackson 2012, p. 56; Grdzelidze 2007, p. 175).

Although Orthodox Christians perhaps emphasize the generally Trinitarian nature of evangelism more strongly than Wesleyans do (Nissiotis 1975, p. 77; Nassif 2004, p. 81), this may be a function of Orthodoxy's tendency to refer everything back to the Trinity (see, for instance, Yannoulatos 2010, p. 8) rather than an actual difference in theological opinion, as there is so much shared understanding as to the role of the persons of the Trinity. Both Wesleyan and Orthodox understandings of evangelism are highly focused on Christ's redemptive work (Tyson 2000, pp. 63, 66; Nissiotis 1975, pp. 75, 78; Lemopoulos 1998, 
pp. 324-25; Damick 2013, p. 16; Wesley 1736, 1780). The primary story being witnessed to is that of Jesus - he is the lynchpin, the one on whom all history turns. Both Traditions see the Incarnation, death, and Resurrection as central-this is the message evangelism seeks to communicate.

In another example of shared understandings, both have very similar views of the role of the Holy Spirit. The Holy Spirit energizes Christians for evangelism, sanctifying them and empowering them to live holy lives and to express the gospel (Tyson 2000, pp. 52, 62, 65; Jackson 2012, pp. 46, 53; Hynson 1982, pp. 33, 35, 36; Nissiotis 1975, pp. 88, 92; Rommen 2017, p. 183; Wesley 1733, 1736, 1785c). The Holy Spirit awakens non-Christians to their sins, providing the conviction that "presses" them toward repentance (Jackson 2012, p. 55; Hynson 1982, p. 35; Nissiotis 1975, p. 77; Nassif 2004, p. 74; Lemopoulos 1998, p. 328; Rommen 2017, p. 199; Outler 1971, p. 46; Grdzelidze 2007, p. 175; Wesley 1760). Additionally, it is the Holy Spirit who is at work in and after conversion, sanctifying and transforming Christians (Nassif 2004, p. 71; Hynson 1982, p. 35; Jackson 2012, p. 53; Lemopoulos 1998, p. 322; Bria 1975, p. 250; Knight and Powe 2006; Charlesworth 2007, p. 68; Wesley 1733, 1736, 1760).

\section{Evangelism: Human Response to the Invitation of the Trinity}

In addition to shared understandings of the work of the Trinity, Wesleyan and Orthodox views hold similar understandings of the role people play in evangelism. First of all, humans retain their agency in reception of the gospel-God reaches out first, but people must respond of their own free will (Tyson 2000, p. 61; Jackson 2012, p. 48; Bria 1984, p. 70; Knight and Powe 2006; Grdzelidze 2007, p. 175; Wesley 1790). Even though it is entirely possible that people will ignore or respond in the negative, rejecting the message of evangelism (Nissiotis 1975, p. 76; Hierarchs of the Standing Conference of the Canonical Orthodox Bishops in the Americas 2000, p. 54), it is absolutely vital that no coercion or manipulation be utilized - $a$ free response to evangelism is the only valid response (Jackson 2012, pp. 48, 56; Hynson 1982, pp. 28, 38-40; Nassif 2004, p. 74). Secondly, humans retain their agency in expression of the gospel-although the natural outflow of the Holy Spirit's work in the Christian is love of God and neighbor, obedience is always invited, never forced (Tyson 2000, p. 52; Wesley 1789; Grdzelidze 2007, p. 175). Instead, God calls his people, offering them the opportunity to be a part of what $\mathrm{He}$ is doing in the world by sharing what has happened in their own hearts through evangelism (Hierarchs of the Standing Conference of the Canonical Orthodox Bishops in the Americas 2000, pp. 61-65; Lemopoulos 1998, p. 328; Rommen 2017, p. 177; Wesley 1786, 1796; Halvorsen 2007, p. 278).

According to both traditions, God has entrusted people with this special task in evangelism-he chooses to work "through human agents" (Jackson 2012, p. 55). Indeed, God's design is that "person-to-person contact" is the way his Good News moves throughout the world (Hierarchs of the Standing Conference of the Canonical Orthodox Bishops in the Americas 2000, p. 59; see also Yannoulatos 2010, p. 27). It is the personal witness of Christian people which allows Jesus Christ to be made known (Hierarchs of the Standing Conference of the Canonical Orthodox Bishops in the Americas 2000, pp. 58, 64, 65; Nissiotis 1975, pp. 80, 91; Antiochian Orthodox Christian Archdiocese Department of Missions and Evangelism 2000; Jackson 2012, p. 51; Lemopoulos 1998, p. 328; Rommen 2017, p. 182; Wesley 1733, 1796).

Finally, both Orthodox Christians and Wesleyans agree that evangelism should be done in a way that is respectfully receiver-oriented; in other words, that the gospel should be communicated in ways that are aimed toward understanding and applicability on the part of those who are hearing (Rack 2002, p. 415). For Wesley, this meant expressing "plain truth for plain people" (Hynson 1982, p. 27; see also Hynson 1982, pp. 28, 30, 37-38, 40; Rack 2002, p. 344) with the goal of genuine, dialogical exchange that allowed the other person to make an informed choice (Hynson 1982, p. 30; see Wesley 1786). Orthodox Christians focus less on the decision-making process, but do think that evangelism should give genuine answers to the questions that people are actually asking (Hierarchs of the 
Standing Conference of the Canonical Orthodox Bishops in the Americas 2000, p. 91; Bria 1984, p. 71). This receiver-orientation of evangelism is also seen in the Orthodox discussion of cross-cultural evangelism: the expression of the gospel in the language and culture of the people, sometimes referred to as "indigenization" of the gospel, is paramount (Nissiotis 1975, pp. 80, 87, 89; Hierarchs of the Standing Conference of the Canonical Orthodox Bishops in the Americas 2000, pp. 90, 93; Lemopoulos 1998, pp. 323, 329; Veronis 1994, p. 123).

\section{Evangelism Leads to Process-Oriented Transformation}

The third major category in which Orthodox Christians and Wesleyans share common understanding is this: there is an expectation that evangelism leads to process-oriented transformation (Tyson 2000, pp. 59-60, 62; Jackson 2012, pp. 50, 54; Hynson 1982, p. 27; Nassif 2004, p. 48; Lemopoulos 1998, p. 323; Fairbairn 2002, p. 8; Wesley 1765; Knight and Powe 2006; Rack 2002, p. 395; Halvorsen 2007, p. 284; Wesley 1733, 1760, 1784, 1785c, 1794). The goal is a new life (Nissiotis 1975, p. 87), that the Christian would become a "new creation" in Christ (Nissiotis 1975, p. 78; Hynson 1982, p. 33). Although conversion is a moment of inflection, it results in a progressive movement in the life of a Christian toward greater holiness-Christians grow more and more Christ-like.

Love of God inspires love of neighbor-this is the joint evidence, process, and result of this transformation (Hopko 1976, pp. 96, 104; Tyson 2000, pp. 52, 66; Hynson 1982, p. 32; Nissiotis 1975, pp. 79, 88; Lemopoulos 1998, p. 326; Chrysostom; Wesley 1733, 1760, 1784, 1796). Out of this love, Christians witness both through but also beyond words, as the way they live their actual lives is revolutionized ((Jackson 2012, p. 51; Hynson 1982, p. 33; Hierarchs of the Standing Conference of the Canonical Orthodox Bishops in the Americas 2000, p. 64; Wesley 1765; Nissiotis 1975, pp. 79, 83, 85, 86, 88; Lemopoulos 1998, p. 324, 326; Abraham 1989, p. 106). This change, the result of evangelism, goes beyond the individual as well-societal structures and cultural contexts are transfigured as Christians actively live out Christ's love in the world (Tyson 2000, pp. 62, 65-66; Hynson 1982, pp. 28, 31, 33-34; Nissiotis 1975, pp. 79, 87, 89-90; Hierarchs of the Standing Conference of the Canonical Orthodox Bishops in the Americas 2000, pp. 98, 100; Bria 1984, p. 68; Lemopoulos 1998, pp. 323, 327, 329; Outler 1971, pp. 25-33; Rack 2002, p. 365, 447).

A key part of this transformation process is being welcomed into a discipling community (Knight and Powe 2006; Wesley 1796; Outler 1971, p. 26). No person can be transformed alone (Wesley 1782; Hierarchs of the Standing Conference of the Canonical Orthodox Bishops in the Americas 2000, p. 102; Tosi 2014, p. 14; Plekon 2007, p. 61; Vassiliadis 2002, p. 101). We need others to encourage, guide, admonish, and invite us deeper into the Christian life (Abraham 1989, p. 54; Knight and Powe 2006). Indeed, it is only as a member of a group that an individual can truly imitate the life-giving love of the Trinity (Vassiliadis 2002, p. 104; Damick 2013, pp. 3, 17).

\section{Key Differences}

Although Wesleyans and Orthodox Christians believe many of the same things about evangelism, it would be a mistake to imply that they are wholly compatible on this topic. On the part of many ecumenically minded authors-myself included - there can be a tendency to overlook or bypass these out of a desire for deeper unity. However, there are very real distinctions between the two, and it would be dishonest to say otherwise (Rommen 2004, p. 249; Jillions 2007, p. 55; see Nikolaev 2007, p. 95). These differences can generally be categorized as: differences in emphasis, intermediate differences, and one key divisive difference.

\section{Differences in Emphasis}

First of all, even within the areas of similarity, there are differences in emphasis. For example, the Orthodox insist upon the inclusion of the entire Trinity in discussions of evangelism, while Wesleyans focus primarily on Christ and the Holy Spirit (see, for 
example, Wesley 1736). Because Orthodox literature referring to the specific role of the Father is scarce, and because the Wesleyan inclusion of the Father seems to me implicit (see, for example, Wesley 1780, 1785a, 1789), this variation seems more a matter of semantics than sense.

Similarly, the Wesleyan spotlight on "justification by faith" referred to by Hynson multiple times seems to be a difference in intensity rather than variety (1982, pp. 27, 28, 29, 39; Wesley 1765; see also Tyson 2000, p. 56; Outler 1971, p. 38; Wesley 1790, 1794). Orthodox Christians share a high regard for the role of faith, seeing it both as given by God and essential for the believer. They would also agree that salvation is a gift from God rather than payment for good works (Wesley 1796, p. 6, 11; Nassif 2004, p. 74; Outler 1971, pp. 44-45; Rack 2002, p. 392). At the same time, Orthodox Christians tend to shy away from this very Protestant way of expressing things. So, the two are in agreement in substance but with differing accentuation.

\section{Intermediate Differences}

In addition to these differences in emphasis, there are differences in approach to evangelism that can be thought of as "intermediate." This label is used because these are more substantial than the previously mentioned divergences but do not, necessarily, bring Wesleyans and Orthodox Christians to a point of conflict. They need to be addressed in more depth than alternative emphases. Although there may be additional differences that fall into this category, the two clearest from the literature examined are Orthodoxy's eschatological focus and Wesley's understanding of sanctification.

Orthodox Christians' understanding of evangelism is highly eschatological, pointed toward the end of all things, in which the entire cosmos is transformed (Nissiotis 1975, pp. 78, 80; Bria 1975, pp. 249-50; Behr 2007, p. 195; Hierarchs of the Standing Conference of the Canonical Orthodox Bishops in the Americas 2000, p. 98; Nassif 2004, p. 55; Rommen 2017, p. 206; Yannoulatos 2010, p. 102). This is the primary goal of evangelism. While Wesleyans certainly see evangelism as affecting more than just individual souls ${ }^{4}$, the restoration of the soul to the original Image of God is the primary action of conversion (Hynson 1982, p. 31; Abraham 1989, pp. 57, 59; Wesley 1736, 1741, 1765, 1784, 1785c, 1794). That which happens after, the change in life that leads to changes in society, is primarily a result.

The Orthodox view of evangelism, on the other hand, approaches redemption from a different angle; ${ }^{5}$ it is focused on the holistic renewal of all created matter (Nissiotis 1975, p. 79; Halvorsen 2007, pp. 274, 277; Yannoulatos 2010, p. 46). The salvation of the individual is part and parcel of the larger picture of the now-but-not-yet Kingdom (Nissiotis 1975, p. 78; Behr 2007, p. 191; Vassiliadis 2002, p. 102; Whiteman 2019; Yannoulatos 2010, p. 48, 49). An evangelism-toward-the Kingdom approach makes Orthodox Christians willing to consider a much wider variety of activities as directly evangelistic. Wesleyans, on the other hand, are more likely to see activities such as feeding the hungry as expressing the love of Christ but not necessarily evangelism. The eschatological-Kingdom-focus of Orthodoxy does not necessarily go against the salvation-of-souls-focus of Wesley. Additionally, the argument can be made that Wesley's idea of "social holiness" which included both Christian community and the transformation of societies, is an effort toward building the Kingdom of God. However, the Orthodox eschatology is undeniably a distinctive.

In a second intermediate difference, the Wesleyan view of sanctification, of becoming more holy and of living a life of love of God and others, though greatly influenced by Orthodox writings (Heitzenrater 2002; Wainwright 2002; Wesley 1775, 1785a; Abraham 1989, p. 9; Vassiliadis 2002, p. 101; Young 2002, pp. 157, 164, 16768), does not line up perfectly with the Orthodox idea of theosis (Nassif 2004, p. 42; Grdzelidze 2007, p. 173; Yannoulatos 2010, p. 47; Stamoolis 1986, p. 9). This goes back to an understanding of what happens in this process: Wesley does see sanctification as the "restored participation of fallen humanity in the Divine life and power," but this is understood to mean that the image of God in each person is being restored 
through the work of the Holy Spirit in the human heart (Tyson 2000, p. 53). The Orthodox understanding of sanctification would go beyond this, to say that this restoration happens through communion with God, through participation in the energies of the life of the Trinity (Nissiotis 1975, p. 78; Shuttleworth 2005; Damick 2013, p. 8; Yannoulatos 2010, p. 46). The Wesleyan understanding of the end goal of evangelism is missing this special relationship which is a "distinctive characteristic" of Orthodox Christian thinking (Hierarchs of the Standing Conference of the Canonical Orthodox Bishops in the Americas 2000, p. 68; Wesley 1741; See Tyson 2000, pp. 53-54). Here, there is more possibility of conflict, as Wesleyans who are perfectly comfortable with Wesley's understanding of sanctification may be uncomfortable with the idea of actual union with God, which is vital to Orthodox understanding of theosis (Hierarchs of the Standing Conference of the Canonical Orthodox Bishops in the Americas 2000, p. 15; Shuttleworth 2005).

\section{Difference That Divides}

There is one primary difference between Orthodox and Wesleyan positions on evangelism that is a major stumbling block to cooperative efforts in this direction: the Eastern Orthodox Church is at the center of evangelism for Eastern Orthodox Christians (Lemopoulos 1998, p. 325; Bria 1975; Yannoulatos 2010, pp. 220-21, 81; Bria 1996, p. 9; Tosi 2014, pp. 7-8; Schmemann 1973, pp. 213-14; Veronis 1982, p. 51; Rommen 2017, p. 209; Jillions 2007, p. 44). Different Orthodox theologians will give different answers to the question, "Are Christians outside the Orthodox Church really Christians?" (See Nikolaev 2007). Nevertheless, it is undeniable that for Orthodox Christians, there is something special about the Eastern Orthodox Church (Stamoolis 1986, pp. 16-17, 98-99). This is because it is in the Church that conversion is made complete through participation in the Sacraments of Baptism and (particularly) Eucharist (Schmemann 1973, p. 215; Tosi 2014, pp. 4, 17; Yannoulatos 2010, p. 113; Cyprian of Carthage 2006, pp. 160, 162, 164; Nikolaev 2007, p. 92; Behr 2007, p. 188; Vassiliadis 2002, p. 107).

Orthodox Christians believe that the Church is the first-fruits and image of the Kingdom (Nissiotis 1975, pp. 77, 84; Vassiliadis 1998, pp. 14, 52); as the Eucharistic Community it is the "taste" of the Trinity that is promised in full at the parousia (Nissiotis 1975, p. 79; See Plekon 2007, p. 59; Vassiliadis 2002, p. 105). This is because through the Sacraments the Church is "an event of communion which reflects in history the Trinitarian existence of God Himself" (Nissiotis 1975, p. 79; See also Behr 2007, p. 196; Vassiliadis 2002, p. 104). God is genuinely present in the Eucharist, allowing human beings to partake of the divine, and the Eucharist only happens in the Church (See Schmemann 1988 for a fuller explanation of Orthodox understanding of what happens in the Eucharist; See also Damick 2013).

Additionally, for the Orthodox, the Church is the tie of the Universal connecting Christians throughout time and space. In the Church, that which has been believed as "Christianity" by all people in all places at all times is re-articulated for new people, places, and times (Rommen 2017, pp. 218-19). The Church tells the stories of two thousand years of martyrs, monastics, and missionaries (See Veronis 1994; Nikolaev 2007, p. 88). It is the carrier of memory, the link between the past, present, and future (Hierarchs of the Standing Conference of the Canonical Orthodox Bishops in the Americas 2000, p. 128; See also Nikolaev 2007, p. 94; Halvorsen 2007, p. 274).

As was mentioned previously, Wesleyans and Orthodox Christians would agree that "there is no such thing as a solitary Christian" (Wesley 1782; Hierarchs of the Standing Conference of the Canonical Orthodox Bishops in the Americas 2000, p. 102; Tosi 2014, p. 14), that Christianity cannot be lived outside of community (Abraham 1989, p. 54). They would also agree that Christianity is about relationship with God and with others (Hierarchs of the Standing Conference of the Canonical Orthodox Bishops in the Americas 2000, p. 113; Hynson 1982, p. 32; Tosi 2014, p. 17). They even agree that there is a historical significance to the Church as Body of Christ (Wesley 1796, pp. 34-41; Outler 1971, p. 55; Rack 2002, p. 291). 
For Orthodox Christians, the Orthodox Church is the location of that community, of those relationships, of that significance. It seems safe to conclude from his laud of the Western Church and denunciation of several branches of the Eastern and Oriental Orthodox Churches as "little, if at all, better than the generality of the Heathens" (Wesley 1783), that Wesley would not agree. Additionally, one must look at Wesley's larger understanding of this topic: Wesley certainly had a category for "the Church" broadly as a mystical body, perhaps even as a Universal (Wesley 1785b). However, that which he spoke of in this sense seems rather more mystical than ecclesial. Indeed, given Wesley's eventual conclusion that the most important thing was to "spread vital religion" (Rack 2002, p. 300) within or beyond the bounds of the Church of England - one could make the argument for a Wesleyan approach that is entirely disconnected from the boundaries of any formal religious institution (Rack 2002, pp. 306, 311; Charlesworth 2007, p. 66; See Wesley 1785b).

Clearly, this is a significant difference between Orthodox and Wesleyans that makes for not one road toward Christ, but two- parallel, similar in many ways, but still twoseparate paths.

\section{A Way Forward}

So, if we are moving down two parallel paths, what are the prospects for Orthodox and Wesleyans working together in evangelistic endeavor? How can we travel these separate tracks together? Two clear areas of joint venture are: dialogue toward renewed self-understanding and service together in the name of Christ.

\section{Dialogue toward Renewed Self-Understanding}

Although many Orthodox are quick to proclaim Orthodoxy as the "one, true Church," they should be the first to admit that there is often a gap between Orthodox tradition/theology and Orthodox practice (Nassif 2004, p. 85). It is true that there are rays of hope, particularly in America. The Antiochian Archdiocese, for one, has long held evangelism in and for America not just as a value but as a way of life. In 2016, the Greek Orthodox Archdiocese's PRAXIS magazine dedicated its Fall/Winter issue to the topic "Speaking to Secular America." Additionally, there are many examples at the parish and individual level of a commitment to evangelism in theory and practice.

At the same time, American Orthodoxy has an overall tendency to turn inward, to count as "evangelism" simply doing Orthodox services and living individual holy lives (Krindatch 2017, pp. 20, 148; See also Tosi 2014). These are certainly essential, but they are not sufficient. It is not just important but necessary to also turn outward-to actively desire the salvation of the whole world and to intentionally seek ways to join God in God's mission in the world and thus to reclaim their core identity as sharers of the gospel.

How does this connect to the earlier conversation detailing differences and similarities in the Orthodox and Wesleyan understandings of evangelism? A significant part of the way forward for both Wesleyans and Orthodox is dialogue with each other. The goal of this mutually enriching discussion is less that the two should teach each other lessons, and more that they might offer each other reminders-that Orthodox and Wesleyans would invite each other to self-reflection that reveals who they genuinely are (See Bria 1984).

Wesleyans can remind Orthodox that their engagement with the world should include their heads, their hands, and their hearts. Wesley and those who follow him most closely evidence a passion for the gospel that goes beyond cold rationality or systematic theology. At their best, Wesleyans show a level of enthusiastic joy that is contagious-if Orthodox Christians delighted in Christ's Resurrection every day in the way that they do on Pascha, what a witness to the world that would be! While some may agree with Metropolitan Kallistos that Orthodoxy is "simple Christianity" (Ware and Neff 2011, p. 39), it is undeniable that the layers of symbolism and Eastern-worldview which inform Orthodoxy can make it seem esoteric and other-worldly in a way that is not always accessible-Wesleyans can also remind Orthodox Christians of the need for practicality and simplicity in evangelism. Orthodox Christians tend to think of things with a long view, one which may cause them 
to forget the immediate. Wesleyans can remind them of the urgency of the evangelistic task - that the building of the Kingdom, the salvation of all people and the whole cosmos is for now.

Orthodoxy has some reminders that would benefit their Wesleyan counterparts who desire to spread the gospel as well. Wesleyans, like many Protestants, may be tempted to think of Christian history as starting with the Reformation, or even with Wesley. This, however, is inconsistent with Wesley himself, who leaned heavily on Christian Patristics and the Book of Common Prayer (Hynson 1982, p. 35), considering himself to be part of a greater Christian continuum. Orthodox can remind Wesleyans of the depth of their Christian roots, of the long history that connects all Christians to Christ. In postmodern America, Wesleyans tend to be isolated and fragmented, frequently leaving behind the idea of formal "bands" or "classes." Orthodox can remind them of the grace of connection and community, of the necessity of Christ-centered, deep, and committed relationships with other Christians.

Wesleyan and Orthodox dialogue in this sense offers a unique opportunity for those who are willing to engage in respectful discussion which neither demands that the other change nor gives up their own true distinctives. Such exchange can be transformative, challenging both Orthodox Christians and Wesleyans to a deeper knowledge of their own Faith Tradition while also inviting each to a unity of their belief and praxis. Both Orthodox Christians and Wesleyans can remind each other of the need for theology which is deeply meaningful and intellectually satisfying precisely because it is applicable to everyday life. Through honest discussion together, Orthodox Christians and Wesleyans can be a part of a lived-theology of humility, repentance, joy, and authentic love.

\section{Joint Service in the Name of Christ}

The second area through which Wesleyans and Orthodox Christians could travel together is joint service in the name of Christ. There are many areas of practical ministry in which the motivation for the "right action" of helping people who are materially poor does not matter. The person receiving shelter, food, a listening ear, or training in job skills can receive Christ's love, likely without caring much about whether that assistance was spurred by Wesley's instruction to visit the sick or Basil's admonishment to share resources.

Once, when he was asked if it was appropriate for Orthodox to support a local ministry, Archbishop Job of Blessed Memory replied: “There ain't nothin' wrong with Methodist soup." Behind this statement is knowledge that the world is full of suffering - so full of pain and need and want that no one group can respond to it all. Orthodox and Methodists should consider pooling their resources, bringing together their "time, talent, and treasure" to help effect greater change than they could on their own.

In Archbishop Job's statement is also the acknowledgement of the good in the other. Both traditions see Christ in the person who is materially poor. That shared perspective should allow Orthodox and Wesleyans to also see Christ in each other. There is potential, then, for Orthodox and Wesleyans to acknowledge their own differences but also to acknowledge the world's suffering and to choose partnership toward its alleviation (See Bria 1984, p. 67). This would be a profound witness to the world that the gospel is truly good news.

FOCUS North America is a wonderful example of this kind of joint service. "FOCUS" stands for both "Fellowship of Orthodox Christians United to Serve" and for "Food, Occupation, Clothing, Understanding, and Shelter." Through its nine Centers and national and state programs, FOCUS serves those living in poverty in the name of Christ. Although "Orthodox" is in the name, FOCUS is an organization that in its practicalities brings together not only Orthodox of different jurisdictions but non-Orthodox Christians and faith-based groups. ${ }^{6}$ In doing so, it exemplifies the willingness to cooperate in whatever ways are possible for the sake of others, out of love for Christ. 


\section{Conclusions}

When it comes to evangelism, Eastern Orthodox and Wesleyan Christians share many positions. Both believe that Christians are called to evangelize, that through evangelism the Trinity is at work, that humanity has a responsibility and freedom in both offering and receiving evangelism, and that the result of evangelism is a transformation-in-process. There are, however, areas of difference as well; some are minor differences in emphasis, others are more significant, and at least one is a church-dividing issue. This difference does not mean, however, that Orthodox and Wesleyans cannot work together: through service to others and through dialogue which reminds them of their own core convictions, cooperative work is possible.

For the first time, the number of adults in the United States who report belonging to a church, synagogue, or mosque has fallen below $50 \%$; all major subgroups are in decline, and nearly a third of respondents report "no religious affiliation" (Jones 2021). "Theological deconstruction" is a trending topic in Evangelical (and Exvangelical) circles (Vanderpool 2021). It is not uncommon to hear evangelism treated like a dirty word, a source of pain and not joy. What is the solution, for Orthodox and Wesleyans who believe that they are called to evangelism even in this climate?

$\varepsilon \dot{\cup} \alpha \gamma \gamma \varepsilon \dot{\varepsilon} \iota \mathrm{\iota}$, the root word for "evangelism", is the combination of the words for "good" and "messenger". In this moment, when it seems that the world is full of people who have not experienced Christians as those who bring "glad tidings of great joy," an opportunity arises: Orthodox and Wesleyans can take this moment to truly and deeply listen to each other and to find their own voices as "good messengers" in the process. They can serve others in the name of Christ, proclaiming His love for each other and for all persons with unity-in-action. They can walk down parallel paths, together toward Christ.

Funding: This research received no external funding.

Institutional Review Board Statement: Not applicable.

Informed Consent Statement: Not applicable.

Data Availability Statement: Not applicable.

Conflicts of Interest: The author declares no conflict of interest.

\section{Notes}

For more information about LOI 2018, see http:/ / www.loimission.net/loi-2018-fulfilling-our-commitment/ (accessed on 1 July 2021). For the remainder of this article, all references to "Orthodox" or "Orthodoxy" refer to the Eastern Orthodox Church, rather than the Oriental Orthodox Church, which is a separate Tradition.

3 For the purposes of this paper, "American Orthodox" or "American Orthodoxy" refers more generally to those Americans who are members of one of the canonical Eastern Orthodox Jurisdictions operating in the United States of America. This is to differentiate from the Orthodox Church in America (OCA), which is a particular Jurisdiction.

4 See earlier discussion of Wesleyan view that social structures would be changed by sanctification.

5 The Orthodox Faith books by Fr. Thomas Hopko do an excellent job of explaining this difference in approach, in a way that is simply not possible here.

6 See, for example, St. Herman House, FOCUS Cleveland https: / / sainthermans.org (accessed on 1 July 2021).

\section{References}

Abraham, William. 1989. The Logic of Evangelism. Grand Rapids: Eerdmans.

Antiochian Orthodox Christian Archdiocese Department of Missions and Evangelism. 2000. Orthodox Evangelism: A Brief Resource Guide for Orthodox Christians. Available online: http://ww1.antiochian.org/sites/default/files/Orthodox_Evangelism_Quick_ Reference_Sheet_Hi_Rez_color.pdf (accessed on 14 January 2021).

Behr, John. 2007. The Eschatological Dimensions of the Church. In Orthodoxy and Wesleyan Ecclesiology. Edited by S. T. Kimbrough. Crestwood: St. Vladimir's Seminary Press, pp. 187-97.

Bria, Ion. 1975. The Church's Role in Evangelism: Icon or Platform? International Review of Mission 64: 243-50. [CrossRef]

Bria, Ion. 1984. Reflections on Mission Theology and Methodology. International Review of Mission 73: 66-72. [CrossRef]

Bria, Ion. 1996. The Liturgy after the Liturgy: Mission and Witness from an Orthodox Perspective. Geneva: WCC Publications. 
Charlesworth, James. 2007. Return to the Sources in Twenty-first-century Methodist Ecclesiology: John Wesley's Ecclesiology in the Light of New Insights into the New Testament and Its Environment. In Orthodoxy and Wesleyan Ecclesiology. Edited by S. T. Kimbrough. Crestwood: St. Vladimir's Seminary Press, pp. 65-86.

Chrysostom, John. 1997. On Living Simply: The Golden Voice of John Chrysostom. Liguori: Triumph Books.

Cyprian of Carthage. 2006. On the Church: Select Treatises. Translated by Allen Brent. Crestwood: St. Vladimir's Seminary Press.

Damick, Andrew. 2013. Why Go to Church? Ancient Faith Topical Series; Chesterton: Ancient Faith Publishing.

Fairbairn, Donald. 2002. Eastern Orthodoxy through Western Eyes. Louisville: Westminster John Knox Press.

Grdzelidze, Tamara. 2007. The Holiness of a Human Being: A Mark of Christian Spirituality. In Orthodoxy and Wesleyan Ecclesiology. Edited by S. T. Kimbrough. Crestwood: St. Vladimir's Seminary Press, pp. 173-84.

Halvorsen, J. Sergius. 2007. Orthodox Eccelsiology from the Perspective of Preaching. In Orthodoxy and Wesleyan Ecclesiology. Edited by S. T. Kimbrough. Crestwood: St. Vladimir's Seminary Press, pp. 271-87.

Heitzenrater, Richard. 2002. John Wesley's Reading of and Reference to the Early Church Fathers. In Orthodox and Wesleyan Spirituality. Edited by S. T. Kimbrough. Crestwood: St. Vladimir's Seminary Press, pp. 25-32.

Hierarchs of the Standing Conference of the Canonical Orthodox Bishops in the Americas. 2000. A Pastoral Letter on the Occasion of the Third Christian Millennium. December 25. Available online: https://www.assemblyofbishops.org/assets/files/news/scoba/ letter-millenium.pdf (accessed on 14 January 2021).

Hopko, Thomas. 1976. The Orthodox Faith: Spirituality. New York: The Department of Religious Education of the Orthodox Church in America.

Hynson, Leon. 1982. A Wesleyan Theology of Evangelism. Wesleyan Theological Journal 17: $26-42$.

Jackson, Jack. 2012. Decoupling Evangelism and Coercion: Early Methodism for Twenty-First Century Mission. Wesleyan Theological Journal 47: 45-58.

Jillions, John. 2007. An Orthodox Reading of 1 Cor. 1:10-31: Any Room for Methodists? In Orthodoxy and Wesleyan Ecclesiology. Edited by S. T. Kimbrough. Crestwood: St. Vladimir's Seminary Press, pp. 43-56.

Jones, Jeffrey. 2021. U.S. Church Membership Falls below Majority for First Time. Gallup News. Available online: https://news.gallup. com/poll/341963/church-membership-falls-below-majority-first-time.aspx (accessed on 26 May 2021).

Justin, Martyr, and Thomas Falls. 1965. Saint Justin Martyr: The First Apology, the Second Apology, Dialogue with Trypho, Exhortation to the Greeks, Discourse to the Greeks, The Monarchy or the Rule of God. Washington: Catholic University of America Press.

Knight, Henry, and F. Dougles Powe. 2006. Transforming Evangelism: The Wesleyan Way of Sharing Faith. Nashville: Discipleship Resources.

Krindatch, Alexei. 2017. Go and Make Disciples: Evangelization and Outreach in US Orthodox Parishes. April 24. Available online: https:/ / www.assemblyofbishops.org/news/news-archive/2017/evangelization-study-report (accessed on 14 January 2021).

Lemopoulos, George. 1998. “Come Our Light, and Illumine Our Darkness!”: Reflections on Evangelism from an Orthodox Perspective. International Review of Mission 87: 322-30.

Nassif, Bradley. 2004. Are Eastern Orthodoxy and Evangelicalism Compatible? Yes: The Evangelical Theology of the Eastern Orthodox Church. In Three Views on Eastern Orthodoxy and Evangelicalism. Edited by Stanley Gundry and James Stamoolis. Grand Rapids: Zondervan, pp. 25-88.

Nikolaev, Sergei. 2007. Bulgakov and Florovsky: In Search of Ecclesiological Foundations. In Orthodoxy and Wesleyan Ecclesiology. Edited by S. T. Kimbrough. Crestwood: St. Vladimir's Seminary Press, pp. 87-103.

Nissiotis, Nikos. 1975. Confessing Christ Today: Reports of Groups at a Consultation of Orthodox Theologians. International Review of Mission 64: 74-94.

Outler, Albert. 1971. Evangelism in the Wesleyan Spirit. Nashville: Tidings.

Plekon, Michael. 2007. Return to the Sources in Twentieth-century Orthodox Ecclesiology: The Case of Nicholas Afasiev. In Orthodoxy and Wesleyan Ecclesiology. Edited by S. T. Kimbrough. Crestwood: St. Vladimir's Seminary Press, pp. 57-64.

Rack, Henry. 2002. Reasonable Enthusiast: John Wesley and the Rise of Methodism, 3rd ed. London: Epworth Press.

Rommen, Edward. 2004. Are Eastern Orthodoxy and Evangelicalism Compatible Maybe: An Orthodox Perspective. In Three Views on Eastern Orthodoxy and Evangelicalism. Edited by Stanley Gundry and James Stamoolis. Grand Rapids: Zondervan, pp. $233-50$.

Rommen, Edward. 2017. Into All the World: An Orthodox Theology of Mission. Yonkers: St. Vladimir's Seminary Press.

Schmemann, Alexander. 1959. Orthodoxy and Mission. St. Vladimir's Seminary Quarterly 3: 41-42. Available online: https:/ / www.schmemann.org/byhim/orthodoxyandmission.html (accessed on 16 April 2021).

Schmemann, Alexander. 1973. Church, World, Mission. Crestwood: St. Vladimir's Seminary Press.

Schmemann, Alexander. 1988. The Eucharist. Crestwood: St. Vladimir's Seminary Press.

Shuttleworth, Mark. 2005. Theosis: Partaking of the Divine Nature. Ben Lomond: Conciliar Press.

Stamoolis, James. 1986. Eastern Orthodox Mission Theology Today. Minnneapolis: Light and Life Publishing.

Tosi, Eric. 2014. Koinonic Evangelism: The Community as the Evangelist. Lausanne-Orthodox Initiative. Available online: https://www.loimission.net/wp-content/uploads/2014/09/Koinonic-Evangelism-Tosi-FINAL.pdf (accessed on 16 April 2021).

Tyson, John. 2000. The Relevance of Wesleyan Evangelism in a Postmodern Culture. Wesleyan Theological Journal 35: $49-68$.

Vanderpool, Kurtis. 2021. The Age of Deconstruction and Future of the Church. Relevant Magazine. Available online: https:/ / www.relevantmagazine.com/faith/the-age-of-deconstruction-and-future-of-the-church/ (accessed on 26 May 2021.). 
Vassiliadis, Petros. 1998. Eucharist and Witness: Orthodox Perspectives on the Unity and Mission of the Church. Brookline: Holy Cross Orthodox Press.

Vassiliadis, Petros. 2002. Holiness in the Perspective of Eucharistic Theology. In Orthodox and Wesleyan Spirituality. Edited by S. T. Kimbrough. Crestwood: St. Vladimir's Seminary Press, pp. 101-16.

Veronis, Alexander. 1982. Orthodox Concepts of Evangelism and Mission. Greek Orthodox Theological Review 27 : 44-57.

Veronis, Luke. 1994. Missionaries, Monks, and Martyrs: Making Disciples of All Nations. Minneapolis: Light \& Life Publishing, Available online: https:/ /www.loimission.net/wp-content/uploads/2013/09/Missionaries-Monks-and-Martrys.pdf (accessed on 16 April 2021).

Wainwright, Geoffrey. 2002. Trinitarian Theology and Wesleyan Holiness. In Orthodox and Wesleyan Spirituality. Edited by S. T. Kimbrough. Crestwood: St. Vladimir's Seminary Press, pp. 59-80.

Ware, Metr Kallistos, and David Neff. 2011. The Fullness and the Center: Bishop Kallistos Ware on Evangelism, Evangelicals, and the Orthodox Church. Christianity Today 55: 38-41.

Wesley, John. 1733. The Circumcision of the Heart. The Sermons of John Wesley. Available online: http://wesley.nnu.edu/johnwesley/the-sermons-of-john-wesley-1872-edition/sermon-17-the-circumcision-of-the-heart/ (accessed on 29 April 2021).

Wesley, John. 1736. On the Holy Spirit. The Sermons of John Wesley. Available online: http://wesley.nnu.edu/john-wesley/thesermons-of-john-wesley-1872-edition/sermon-141-on-the-holy-spirit/ (accessed on 29 April 2021).

Wesley, John. 1738. Salvation by Faith. The Sermons of John Wesley. Available online: http://wesley.nnu.edu/john-wesley/thesermons-of-john-wesley-1872-edition/sermon-1-salvation-by-faith/ (accessed on 29 April 2021).

Wesley, John. 1741. Christian Perfection. The Sermons of John Wesley. Available online: http://wesley.nnu.edu/john-wesley/thesermons-of-john-wesley-1872-edition/sermon-40-christian-perfection/ (accessed on 27 April 2021).

Wesley, John. 1750. Upon our Lord's Sermon on the Mount: Discourse Thirteen. The Sermons of John Wesley. Available online: http:/ / wesley.nnu.edu/john-wesley/the-sermons-of-john-wesley-1872-edition/sermon-33-upon-our-lords-sermon-onthe-mount-discourse-thirteen/ (accessed on 27 April 2021).

Wesley, John. 1760. The New Birth. The Sermons of John Wesley. Available online: http://wesley.nnu.edu/john-wesley/the-sermonsof-john-wesley-1872-edition/sermon-45-the-new-birth/ (accessed on 29 April 2021).

Wesley, John. 1765. The Scripture Way of Salvation. The Sermons of John Wesley. Available online: http://wesley.nnu.edu/johnwesley/the-sermons-of-john-wesley-1872-edition/sermon-43-the-scripture-way-of-salvation/ (accessed on 16 April 2021).

Wesley, John. 1775. On the Trinity. The Sermons of John Wesley. Available online: http://wesley.nnu.edu/john-wesley/the-sermonsof-john-wesley-1872-edition/sermon-55-on-the-trinity/ (accessed on 16 April 2021).

Wesley, John. 1780. Spiritual Worship. The Sermons of John Wesley. Available online: http://wesley.nnu.edu/john-wesley/thesermons-of-john-wesley-1872-edition/sermon-77-spiritual-worship/ (accessed on 27 April 2021).

Wesley, John. 1782. God's Love to Fallen Man. The Sermons of John Wesley. Available online: http:/ /wesley.nnu.edu/john-wesley/ the-sermons-of-john-wesley-1872-edition/sermon-59-gods-love-to-fallen-man/ (accessed on 29 April 2021).

Wesley, John. 1783. The General Spread of the Gospel. The Sermons of John Wesley. Available online: http://wesley.nnu.edu/johnwesley/the-sermons-of-john-wesley-1872-edition/sermon-63-the-general-spread-of-the-gospel/ (accessed on 28 April 2021).

Wesley, John. 1784. On Perfection. The Sermons of John Wesley. Available online: http:/ /wesley.nnu.edu/john-wesley/the-sermonsof-john-wesley-1872-edition/sermon-76-on-perfection/ (accessed on 28 April 2021).

Wesley, John. 1785a. The New Creation. The Sermons of John Wesley. Available online: http://wesley.nnu.edu/john-wesley/thesermons-of-john-wesley-1872-edition/sermon-64-the-new-creation/ (accessed on 28 April 2021).

Wesley, John. 1785b. Of the Church. The Sermons of John Wesley. Available online: http://wesley.nnu.edu/john-wesley/the-sermonsof-john-wesley-1872-edition/sermon-74-of-the-church/ (accessed on 28 April 2021).

Wesley, John. 1785c. On Working Out Our Own Salvation. The Sermons of John Wesley. Available online: http:/ /wesley.nnu.edu/johnwesley/the-sermons-of-john-wesley-1872-edition/sermon-85-on-working-out-our-own-salvation/ (accessed on 28 April 2021).

Wesley, John. 1786. On Visiting the Sick. The Sermons of John Wesley. Available online: http://wesley.nnu.edu/john-wesley/thesermons-of-john-wesley-1872-edition/sermon-98-on-visiting-the-sick/ (accessed on 29 April 2021).

Wesley, John. 1788. On Conscience. The Sermons of John Wesley. Available online: http://wesley.nnu.edu/john-wesley/the-sermonsof-john-wesley-1872-edition/sermon-105-on-conscience/ (accessed on 16 April 2021).

Wesley, John. 1789. The Unity of the Divine Being. The Sermons of John Wesley. Available online: http://wesley.nnu.edu/johnwesley/the-sermons-of-john-wesley-1872-edition/sermon-114-the-unity-of-the-divine-being/ (accessed on 27 April 2021).

Wesley, John. 1790. Free Grace. The Sermons of John Wesley. Available online: http://wesley.nnu.edu/john-wesley/the-sermons-ofjohn-wesley-1872-edition/sermon-128-free-grace/ (accessed on 27 April 2021).

Wesley, John. 1794. On Patience. The Sermons of John Wesley. Available online: http:/ /wesley.nnu.edu/john-wesley/the-sermons-ofjohn-wesley-1872-edition/sermon-83-on-patience/ (accessed on 29 April 2021).

Wesley, John. 1796. An Earnest Appeal to Men of Reason and Religion, 8th ed. London: Printed for G. Whitfield, Available online: http:/ / divinityarchive.com/handle/11258/16722 (accessed on 27 April 2021).

Whiteman, Kristina. 2019. Blessed Is the Kingdom: The Divine Liturgy as Missional Act. The Asbury Journal 74: 323-46. Available online: https: / / place.asburyseminary.edu/cgi/viewcontent.cgi?article=2472\&context=asburyjournal (accessed on 26 May 2021).

Whiteman, Darrell, and Gerald Anderson, eds. 2009. World Mission in the Wesleyan Spirit. Franklin: Seedbed Publishing. 
Yannoulatos, Anastasios. 2010. Mission in Christ's Way. Brookline: Holy Cross Press.

Young, Frances. 2002. Inner Struggle: Some Parallels between the Spirituality of John Wesley and the Greek Fathers. In Orthodox and Wesleyan Spirituality. Edited by S. T. Kimbrough. Crestwood: St. Vladimir's Seminary Press, pp. 157-72. 